\title{
A 2011 REVIEW: COMPUTER LITERACY REQUIREMENTS FOR BACHELOR'S DEGREE PROGRAMS IN U.S. PUBLIC UNIVERSITIES AND COLLEGES OF BUSINESS
}

\author{
Betty Kleen, Nicholls State University, betty.kleen@nicholls.edu \\ Sherry Rodrigue, Nicholls State University, sherry.rodrigue@nicholls.edu \\ Ronnie Fanguy, Nicholls State University, ronnie.fanguy@nicholls.edu
}

\begin{abstract}
This study investigated the current status of computer literacy requirements in public universities and their colleges of business throughout the U.S. A review of 274 public universities accredited by the six regional accrediting organizations recognized by the Council for Higher Education and the U.S. Department of Education revealed a split decision as to whether computer literacy is mandated as part of core competencies to be completed in all bachelor's degree programs or whether it is expected of entering students. Even though less than $50 \%$ specified computer literacy competency in their liberal arts or general education core coursework, over $60 \%$ of the colleges of business within those schools do include a computer literacy course within their core or pre-business core curriculum requirements. Most often the course is offered in a three-credit-hour format. Options such as competency tests (or remedial modules or coursework for those who do not pass the test) are specified at some institutions instead of a required course.
\end{abstract}

Keywords: Computer Literacy, Computer Instruction, General Education Bachelor’s Degree Curriculum

\section{INTRODUCTION}

Thirty years ago, colleges and universities throughout the U.S. were stepping up to address how to prepare students to work with the newly emerging desktop computers rapidly being purchased for home and business use. Many schools implemented computer literacy as a requirement and often placed a requirement of this literacy into the school's liberal education (general education) core requirements for all graduates.

In early years of the desktop computers (remember the $4 \mathrm{~K}, 8 \mathrm{~K}, 16 \mathrm{~K}$, and $48 \mathrm{~K}$ machines?) students often received instruction in learning operating system commands, some introductory work with word processing software or spreadsheet software considered very cumbersome by today's standards, and perhaps some programming in a language such as Basic. Over the last three decades the computer literacy course has typically evolved in an attempt to keep pace with technology and to effectively facilitate individuals' interaction with and use of technology in their careers. If schools were to calculate all the funds that have been invested in computer lab hardware and software upgrades and faculty salaries for those who have taught computer literacy courses over the past three decades, the sums would be sobering indeed.

Although we may chuckle at the clever E*TRADE advertising that shows babies using technology, the reality is that today's very young children are using technology for communication, games, and learning. Wherever one might be in a public setting, it is not unusual to find a child explaining something about an iPhone, iPad, etc., to a parent or grandparent. With all the mobile computing options and capabilities that have emerged in recent years and the reality of the millennial generation's long-time use of technology prior to arriving on the typical college campus, one has to wonder what colleges and universities are doing in 2011.

Today's tight higher education budgets in virtually every state can mean limited dollars for updating computer labs. Those same tight budgets can often tax faculty resources by requiring heavier teaching loads. In disciplines such as computer science and computer information systems, having to devote faculty resources to a computer literacy course for all majors can even negatively impact the number and frequency of higher-level courses for students majoring in computer science or computer information systems. 
This paper takes a look at the current status of computer literacy requirements across the country in public universities. Do schools continue to invest significant dollars in hardware and faculty resources (especially computer science or computer information systems faculty) and require a computer literacy course of all bachelor's degree students? Do college of business curricula include a computer literacy requirement even though the general university requirements do not mandate it? Does the higher education perception of the need for a college-level computer literacy course differ from region to region across the country? This study provides answers to these questions.

\section{HOW COMPUTER LITERACY HAS EVOLVED—REFLECTIONS FROM THE LITERATURE}

In the early 1980's, institutions regrouped to provide students in all majors with a course that would help them develop "literacy" in use of the emerging desktop computers, recognizing that the curricula needed to prepare students for their future professional environments. Providing this new literacy required developing specific courses concentrating on computer literacy elements and content.

\section{Current Computer Literacy Definitions}

Most likely it would require a significant amount of debate to reach a common definition for computer literacy just among those attending a single computer-related conference. Topics such as knowledge of hardware, operating systems, and use of application software for such tasks as word processing, spreadsheet creation, and electronic communications receives mention in current definitions of computer literacy found in BusinessDictionary.com [2] and the PC Magazine Encyclopedia [3]. Additionally, Computer Literacy USA [4] extends the above description somewhat by stating, "It is the essential knowledge needed to function independently with a computer ... being able to solve and avoid problems, adapt to new situations, keep information organized ...." This same organization contends that lack of a clearly established definition of computer literacy contributes to less than effective results in teaching computer literacy. In fact, the organization suggests, "many, if not most, college students (as well as faculty and staff) are barely functional.”

\section{From the 1980's Until Today}

Some may well remember the days of first starting to teach students about microcomputers and the arrival of the first microcomputers on campus for computer labs. Faculty began teaching students about operating system commands so they could load and run independent, cumbersome software that allowed limited word processing, spreadsheets or database activities, with difficult or non-existent integration of the packages. No doubt many of those courses for a number of years also held on to content that required students to also learn to do a little programming in a language such as Basic. Obviously computer literacy is an area where content continued to evolve as the technology advanced.

Kieffer's 1995 description of computer literacy courses for all students was one that no doubt could describe computer literacy content at many schools across the country at that time [12]. Kieffer's content actually involved both a non-credit course and a second, for credit course and included the following: computer components, operating systems, word processing, graphics, spreadsheets, database, library databases, telecommunications, and Internet.

Moving forward from 1995, obviously much has changed in computer hardware and software in the last 15 years, bringing more applications with more task capabilities and the ubiquitous mobile computing that people from ages 2 to 102 have come to embrace. This has provided many challenges to schools in determining how and when to upgrade the content and/or focus of the computer literacy course or even whether to remove it as a curriculum mandate as more and more millennial students enter higher education as freshmen.

In a recent 2011 conversation with writer Mary Grush [6], Sherry Turkle, a professor at MIT, concludes that students today do not possess sufficient technological literacy. Turkle's concern for students' "digital literacy” even 
raises the question as to whether the computer literacy course should be retained, renamed, and content modified again.

\section{ARE TODAY'S COLLEGE FRESHMEN ALREADY COMPUTER LITERATE?}

Over the past ten years, researchers such as McCoy [15], Jennings and Wilson, [9], and Jennings, Wilson, Rucker and Braathen [10] are just a few of the educators who have researched software tools most important for technical competency. Not surprisingly, various office productivity software applications such as word processing, spreadsheets, presentation graphics, e-mail, and database are identified frequently, in addition to Internet usage.

In 2005, Hoffman and Vance [8] surveyed first-year students to compare what they already knew to content in the institution's computer literacy courses. Interestingly, many students reported learning many of the tasks included in the survey on their own rather than through a structured course. Within a similar research period, Case, MacKinnon and Dyer [1] found that only one out of 82 students who took a computer literacy assessment test in an attempt to test out of the institution's computer concepts course scored high enough to pass the test; this occurred even though a very high percentage of students self-reported having completed one or more computer courses previously (in high school, junior high, etc.). In 2009 Kilcoyne et al looked at student confidence in mastery of technology and whether or not students' general confidence in their mastery of technology is actually representative of their knowledge [13]. Students averaged $42 \%$ on the test administered, and the authors concluded "students taking the test greatly overestimated their mastery of technology.”

Others researchers have also had similar interests in course content and the computer literacy students bring with them when they enter higher education. Dufrene, Clipson, and Wilson's 2010 study also examined first-year college students to identify their self-efficacy of computer application skills [5]. Results showed that students self-reported "stronger than moderate skills in word processing, file management, presentation applications, and spreadsheet applications.”

Karsten and Schmidt compared computer self-efficacy of a 1996 class of students to a 2006 class of students [11]. Their ten-year comparison revealed that the 2006 students actually had lower computer self-efficacy than the 1996 students, despite more computer use and experience. The authors noted that while students make frequent use of online computing such as email, instant messaging, text messaging, social networks and web browsing, that online computer interaction is more extensive than the off-line uses of certain common productivity software.

Similarly, McLennan and Gibbs conducted a longitudinal study comparing students in 1999 with students in 2008 for computing confidence [16]. These researchers found students in 2008 to more likely do computing online; students had overall higher confidence than the earlier students. However, the results also showed 2008 students less competent in productivity software such as spreadsheets and databases.

In 2010 Heinrichs and Lim [7] also studied students' perceived functional skills and competency in word processing and presentation tools and concluded that to enhance students' information literacy, use of application productivity software needs to be integrated into higher education academic curriculums. In that same study, the authors reported that students surveyed indicated a desire for a higher level of skills in those areas.

As the above paragraphs reflect, studies regarding college students' computer competency show mixed findings; some studies would suggest no computer literacy course is needed in higher education, while others suggest student competency in key productivity packages is lacking. From the current researchers' perspective, the results indicating minimum skill levels are not necessarily surprising, since many students may not have continued their use of spreadsheet or database software after learning it in a junior high or freshman high school course. With all the upgrades and modified, enhanced, and expanded functions each new software release brings, it is no surprise that it is not as easy as the old adage of "it's just like riding a bicycle after a number of years without doing so - once you get back on it, it all comes back to you." Is it really so surprising that a student's self-efficacy regarding offline software productivity tools, computer components, and use of software for problem solving support is not up to higher education faculty expectations? 
In the fall of 2010, Kleen and Rodrigue [14] researched public universities in Arkansas, Louisiana, New Mexico, Oklahoma and Texas and found that one-third of the schools currently mandate a computer literacy requirement for all bachelor's degree students. Slightly over $60 \%$ of the schools included in that study did include a computer literacy course within the college of business pre-business or business core curriculum. Based on the information found in the five-state study, it can be beneficial, therefore, to investigate whether institutions in other regions of the U.S. are retaining computer literacy requirements as part of their curricula or removing those requirements as the curricula decision makers perceive students are entering the institution with those competencies already achieved.

\section{RESEARCH PROBLEM AND METHODOLOGY}

The authors of the current study elected to expand on recent research on the status of computer literacy in public universities within Arkansas, Louisiana, New Mexico, Oklahoma, and Texas [14]. The current project includes accredited public universities from across the U.S. that offer a bachelor's degree or higher. Specifically, the following research questions were identified:

1. How frequently is computer literacy specifically referenced in the general education component (sometimes referred to as liberal arts or core curriculum) of bachelor’s degree curricula at public universities?

2. How many credit hours are required to meet computer literacy or competency?

3. Do colleges/schools of business within the universities reviewed require computer literacy within their "core" or "business foundation"

coursework?

4. How many credit hours do colleges/schools of business require in computer literacy?

The websites of the six major regional accreditation bodies that have been recognized by the Council for Higher Education Accreditation (CHEA) and the U.S. Department of Education (USDE) were searched, and all public institutions offering at least bachelor's degrees were identified. These accrediting bodies included the following:

- Middle States Association of College and Schools Middle States Commission on Higher Education [17]

- New England Association of Schools and Colleges Commission on Institutions of Higher Education [18]

- North Central Association of College and Schools The Higher Learning Commission [19]

- Northwest Commission on Colleges and Universities [20]

- Southern Association of Colleges and Schools Commission on Colleges [21]

- Western Association of Schools and Colleges Accrediting Commission for Senior Colleges and Universities [22]

Those institutions clearly identified as specialty schools such as medicine, law, and so forth were excluded. A systematic sampling technique was used to select one-half of the remaining public colleges and universities in each state. The current online undergraduate catalog of each school was then reviewed to gather information to answer each of the above research questions. The researchers elected to search catalogs specifically instead of contacting schools directly because of frequent low response rates of surveys. Searching catalogs specifically could include more schools in the analysis. While a vice president of academic affairs office may have been a logical office to receive a survey about general education computer literacy requirements, the likelihood of a vice president completing such a survey was perceived to be very minimal by the current researchers.

The researchers designed a spreadsheet template to help ensure that comparable information was gathered and recorded from each school. In addition to reviewing the general education discussion and course requirements within each school's current undergraduate catalog, the researchers also drilled down further in the catalogs and identified the course discipline and number, course title, and course description of any computer courses required of all majors in the college/school of business. This helped determine whether a "literacy" course was actually 
required or whether the college moved students directly to a course with higher-level content and focus in information systems.

\section{FINDINGS}

The researchers reviewed the current online undergraduate catalogs of 274 public universities within the fifty states. Due to the nature of the data collected, the authors have chosen to display the results in graphs that show frequency of specific criteria. The data at present do not support analysis of correlations or regressions. In future studies, as more information is collected from individual schools and course syllabi, more complex analysis may be possible.

As shown in Figure 1, approximately two-thirds of the institutions were located either in the Southern Region, encompassing 10 states, or the North Central Region, encompassing 19 states.

Figure 1: Number of Universities

Researched by Region

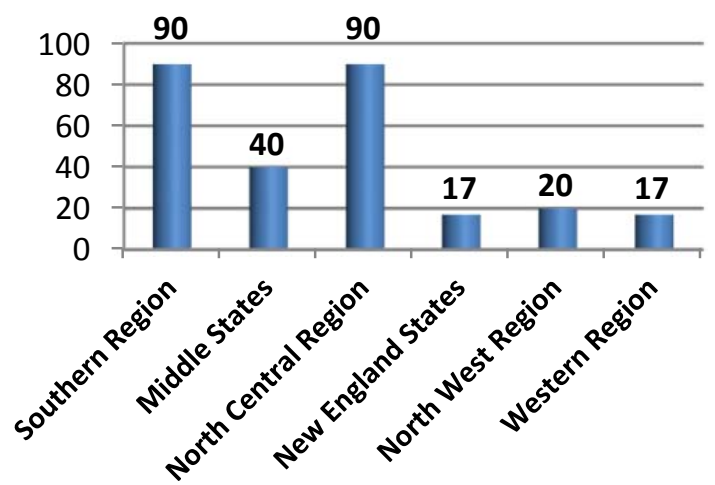

Of the 274 public universities, less than half the schools included specific catalog statements that made reference to computer literacy and/or competency being expected of their graduates when listing information related to bachelor's degree requirements and/or general education requirements (see Figure 2). Furthermore, only about half of those schools provided a specific computer literacy requirement. In a number of schools where computer literacy skills were expected, statements were linked to use of the computer for communicating and researching and to such courses as Freshman English or writing courses. A few schools specified that computer literacy was integrated across the curriculum. While some schools clearly identified a small group of courses that would fulfill the computer literacy requirement, other schools noted that the decision of how students would achieve the competency was left to the individual programs.

Figure 2: Computer Literacy Expectations and Requirements

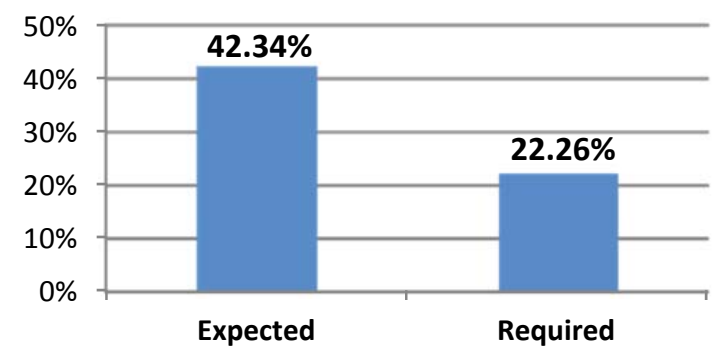




\section{Volume XII, No. 2, pp 162-170, 2011}

The Southern Region led in number of schools specifically listing computer literacy expectations of all bachelor's degree students (see figure 3). The 42 southern region schools that declared computer literacy expectations were approximately $50 \%$ of all southern schools researched.

Figure 3: Universities with Computer Literacy Expectancies by Region

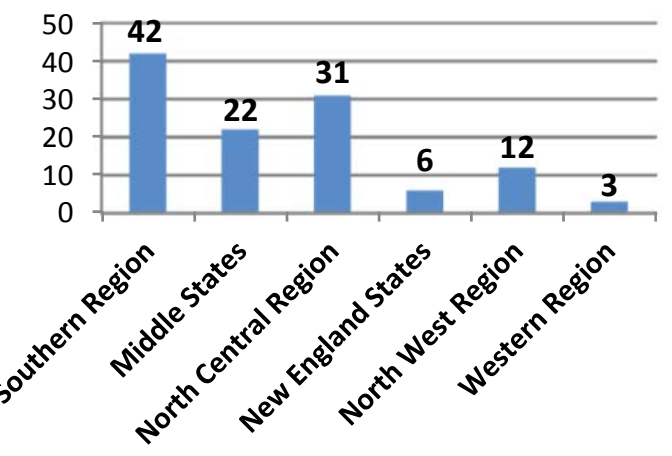

Figure 4 represents the number of schools that moved beyond wording of expectancy of computer literacy to actually requiring a computer literacy course through the general education core for all majors. As Figure 4 illustrates, the North Central Region led in the actual number of schools with a specific computer literacy requirement in the general education core.

\section{Figure 4: Universities with Computer Literacy Requirements in General Education Core by Region}

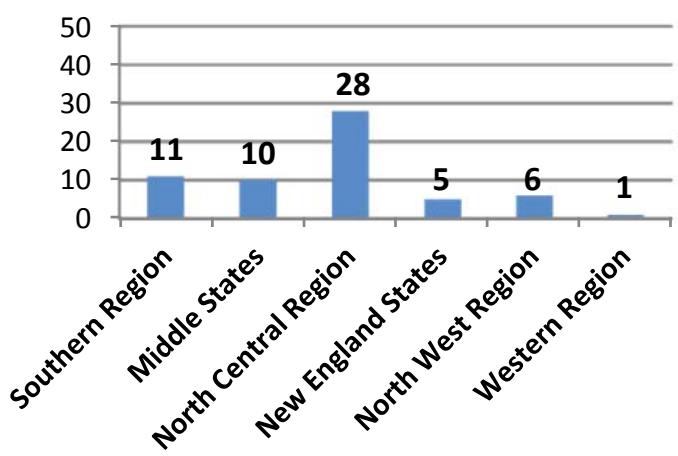

Figure 5 illustrates that when credit hours of computer literacy were mandated at the university level, the most common requirement was a three-credit course, although a small percentage of schools specified as many as six credit hours. 
Volume XII, No. 2, pp 162-170, 2011

Figure 5: Credit Hours of Computer Literacy Required

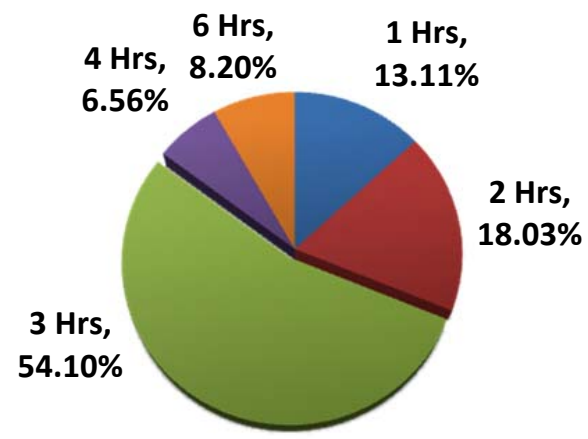

For schools requiring $>0$ hours, $n=61$

Research specifically related to the college of business required curricula in each school in the study revealed some interesting findings. Within the 90 schools researched in the Southern Region, 78 colleges of business included a computer literacy requirement in the business core. In the 90 schools in the North Central Region, 60 colleges of business included a computer literacy requirement in the business core. (See Figure 6.) At some institutions the college of business taught the course within one of its departments; in other schools the literacy course was handled through other colleges, such as within a computer science department or an interdisciplinary studies department. A limitation to the research in this current study is that not all catalog course descriptions provided sufficient details; further research will be necessary to gather a complete understanding of commonality and/or differences in content and focus of the designated computer literacy courses being taught.

Figure 6: Computer Literacy

Requirements: General Education Core

vs. College of Business Core

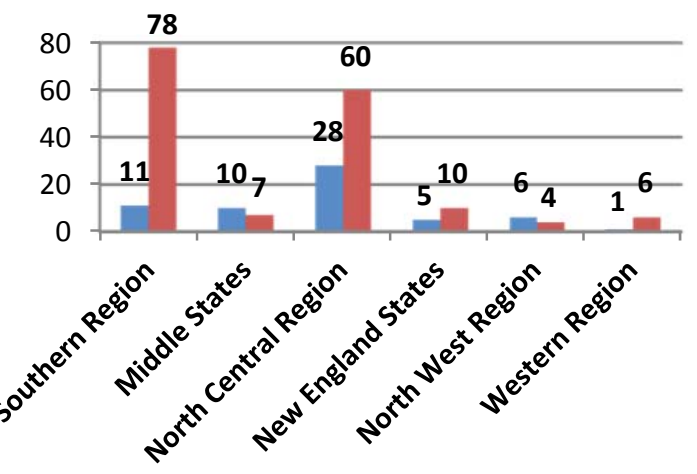

Requirement in General Education Core

Requirement in College of Business Core

Figure 7 shows that $90 \%$ of the colleges of business with a core computer literacy requirement provide the instruction in a three-credit-hour course. In some schools where computer literacy was not mandated in the business core, students were required to pass a competency exam or successfully complete either a credit or noncredit course that would not count toward the degree (most often in freshman year). 
Volume XII, No. 2, pp 162-170, 2011

Figure 7: Credit Hours of Computer Literacy Required in College of Business

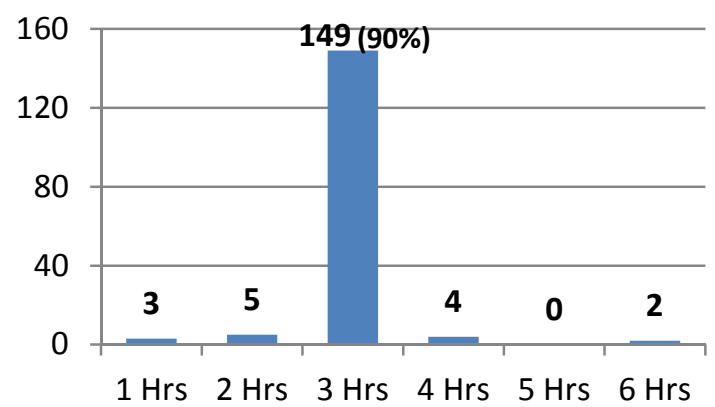

\section{CONCLUSIONS AND RECOMMENDATIONS}

This study provides a spring 2011 report of computer literacy expectations within 274 accredited public universities across the United States. Based on a review of current undergraduate catalogs of the schools, approximately $40 \%$ of surveyed schools mention computer literacy within the liberal arts (general education) core requirements for all bachelor's degree students. Based on identified course disciplines and numbers, course titles, and descriptions, the researchers concluded that over $60 \%$ of the researched colleges/schools of business continue to require computer literacy coursework in their pre-business or business core curriculum, most often in a three-credit-hour course requirement. Thus many schools are continuing to invest faculty resources in teaching computer literacy.

As noted earlier, the authors elected to look directly at university catalogs to gather information for this study. Although the course titles and catalog descriptions were identified within this study, some course descriptions were too generic to identify focus and/or content clearly. Additionally, some course descriptions may be out of date in comparison as to what is actually currently included in the course content listed in current syllabi. In future research, the authors plan to gather course syllabi from the departments offering the courses identified in this study to determine more specific content. This will facilitate identifying the commonalities and/or differences in content and focus that exist.

The researchers also recommend that institutions consider an annual administration of a computer self-efficacy survey to some of the entering freshmen to help determine students' computer backgrounds and confidence in skills areas faculty deem important aspects of today's computer literacy.

\section{REFERENCES}

1. Case, T., MacKinnon, R., \& Dyer, J. (2004). Computer literacy and the introductory student: An analysis of perceived and actual knowledge of computers and computer applications. SAIS 2004 Proceedings. Paper 46.

2. Computer literacy. (2011). Retrieved from http://www.businessdictionary.com/definition/computerliteracy.html.

3. Computer literacy. (2011). Retrieved from http://www.pcmag.com/encyclopedia term/0,t=\&i+40158,00.asp.

4. Computer Literacy USA. (2011). The Computer Literacy Initiative. What is computer literacy? Retrieved from http://computerliteracyusa. web.officelive.com/default.aspx.

5. DuFrene, D., Clipson, T., \& Wilson, A. (2010). Measuring college students' technology self-efficacy. Association of Business Information Systems 2010 Refereed Proceedings, 13-20.

6. Grush, M. (2011). Rethinking technological literacy: Reflections on a conversation with Sherry Turkle. Retrieved from http://campustechnology.com/Articles/2011/05/11Rethinking-Technological-Literacy.asp.

7. Heinrichs, J. H., \& Lim, J. (2010). Information literacy and office tool competencies: A benchmark study. Journal of Education for Business, 85, 153-164. 
8. Hoffman, M., \& Vance, D. (2005). Computer literacy: What students know and from whom they learned it. Proceedings of the $36^{\text {th }}$ SIGCSE technical symposium on Computer Science education.

9. Jennings, S. E., \& Wilson, A. (2006). Are we teaching the computer application skills employers need? Association of Business Information Systems 2006 Refereed Proceedings, 57-62.

10. Jennings, S. E., Wilson, S. A., Rucker, J., \& Braathen, S. (2007). Computer application employability skills. Association of Business Information Systems 2007 Refereed Proceedings, 11-16.

11. Karsten, R., \& Schmidt, D. (2008). Business student computer self-efficacy: Ten years later. Journal of Information Systems Education, 19(4), 445-453.

12. Kieffer, L. (1995). Establishing a computer literacy requirement for all students. In Emerging Technologies, Lifelong Learning, NECC '95. ERIC ED 392436.

13. Kilcoyne, M. S., McDonald, J., Hanson, B., Champion, S., Garland, M., \& Maples, G. (2009). Can they really walk the talk? Association of Business Information Systems 2009 Refereed Proceedings, 55-60.

14. Kleen, B, \& Rodrigue, S. (2011). Computer literacy requirements in public universities in the Southwestern region of the U.S.: A 2010 Review. Association of Business Information Systems 2011 Refereed proceedings, 41-46.

15. McCoy, R. W. (2001). Computer competencies for the 21st century information systems educator. Information Technology, Learning, and Performance Journal, 19(2), 21-35.

16. McLennan, T., \& Gibbs, S. (2008). Has the computing competence of first year university students increased during the last decade? In Hello! Where are you in the landscape of educational technology? Proceedings ascilite Melbourne 2008. http://www.ascilite.org.au/ conferences/melbourne08/procs/mclennan.pdf.

17. Middle States Commission of Colleges and Schools Middle States Commission on Higher Education. (2011). Institution Directory. Retrieved from http://www.msche.org/ institutions_directory.asp.

18. New England Association of Schools and Colleges Commission on Institutions of Higher Education. (2011). Roster of Institutions. Retrieved from http://cihe.neasc.org/ about_our_institutions/roster_of_institutions/.

19. North Central Association of Colleges and Schools, The Higher Learning Commission. (2011). Directory of institutions. $\quad$ Retrieved from http://www.ncahlc.org/component/ option,com_directory/Itemid,184/.

20. Northwest Commission on Colleges and Universities. (2011). Directory of Institutions. Retrieved from http://www.nwccu.org/ Directory\%20of\%20Inst/Diredtory\%20of\%20Institutions.htm.

21. Southern Association of Colleges and Schools, Commission on Colleges. (2011). Membership directory. Retrieved from http://www.sacscoc .org/membershipInfo.asp

22. Western Association of Schools and Colleges Accrediting Commission for Senior Colleges and Universities. (2011). Directory of Institutions. Retrieved from http://www.wascsenior.org/ directory/institutions. 